\title{
Genetically engineered (modified) crops (Bacillus thuringiensis crops) and the world controversy on their safety
}

\author{
Mohamed Samir Tawfik Abbas
}

\begin{abstract}
Bacillus thuringiensis (Bt) crops are plants genetically engineered (modified) to contain the endospore (or crystal) toxins of the bacterium, Bt to be resistant to certain insect pests. In 1995, the Environmental Protection Agency (EPA) in USA approved the commercial production and distribution of the Bt crops: corn, cotton, potato, and tobacco. Currently, the most common Bt crops are corn and cotton. The crystal, referred to as Cry toxins, is proteins formed during sporulation of some Bt strains and aggregate to form crystals. Such Cry toxins are toxic to specific species of insects belongs to orders: Lepidoptera, Coleoptera, Hymenoptera, Diptera, and Nematoda. In 2016, the total world area cultivated with genetically modified crops (GM crops) reached about 185 million ha. This review shows that there is a worldwide controversy about the safety of Bt crops to the environment and mammals. Some researchers support the cultivation of Bt crops depending upon the results of their laboratory and field studies on the safety of such crops. Others, however, are against Bt crops as they may cause risk to human.
\end{abstract}

Keywords: Genetically modified crops, Bt crops, Genetically engineered organisms, GMO

\section{Background}

When a gene from one organism is transferred to improve or induce desired change in another organism, in laboratory, the result is a genetically engineered (or modified) organism (which may also called transgenic organism). There are different methods to transfer genes to animals and plants where the old and most traditional one is through the selective breeding. For example, a plant with a desired trait is selected and bred to produce more plants with such a trait. Recently, with the reached high technology, advanced techniques are carried out in laboratory to transfer genes that express the desired traits from a plant to a new plant (Martineau 2001).

The first produced genetically modified plant in the laboratory was tobacco in 1983 and was tested in 1986 as herbicide-resistant in France and the USA. In 1994, the European Union approved the commercial production of the plant as resistant to the herbicide bromoxynil (Martineau 2001).

Correspondence: samra_mst@hotmail.com

Department of Biological Control, Plant Protection Research Institute, Dokki, Giza, Egypt

Springer Open
Tomato was the first commercially grown genetically modified whole food crop (called FlavrSavr) which was modified to ripen without softening by a Californian company, Calgene (Martineau 2001). Calgene took the initiative to obtain the Food and Drug Administration (FDA) approval for its release in 1994. It was welcomed by consumers who purchased the fruit at high price. However, a conventionally bred variety with longer shelf-life prevented the product from becoming profitable.

\section{World cultivation of commercialized GM crops}

In 1997, the total cultivated area of GM crops was 1.7 million ha and increased gradually to reach 185.1 million ha in 26 countries in 2016; 19 of these are developing countries beside 7 industrial countries. The GM crops include, mainly, 5 crops: two of them (corn and cotton) are resistant to insects alone or to insects and herbicides together. The other three (soybean, canola and sugar beet) are resistant to herbicides. The area of GM crops in the developing countries in 2016 was 99.6 million ha (54\%) while it was 85.5 million ha (46\%) in the industrial ones. USA grew 72.9 million ha (representing $39 \%$ of the world total area), Brazil (27\%), Argentina (13\%), Canada (6\%), India (6\%), Paraguay 
(2\%), Pakistan (2\%), China (2\%), and South Africa (1\%). Five European countries (Spain, Portogal, Czec Republic, Slovakia, and Romania) planted about 117,000 ha in 2015 that increased to 136,000 ha in 2016. Romania decided not to plant in 2016 due to onerous requirement by the government (James 2016).

Genetically engineered products are not new. Insulin used in medicine is an example of genetic engineering. Genes encoding human insulin were cloned and expressed in E. coli in 1978. At present, insulin is being produced in E.coli and the yeast Saccharomyces cerevisiae for diabetic patients (Baeshen et al. 2014).

\section{How to produce genetically modified crops}

Rani and Usha (2013) mentioned that the modified crops are produced by:

1. Identifying and locating genes for plant traits, which is the most limiting step in the transgenic process. Identifying a single gene involved with a trait is not sufficient; scientists must understand how the gene is regulated, what other effects is might have on the plant and how it interacts with other genes active in the same biochemical pathway.

2. Designing genes for insertion, but once a gene has been isolated and cloned (amplified in a bacterial vector), it must undergo several modifications before it can be effectively inserted into a plant.

3. Transforming plants, which is the heritable change in a cell or organism brought about by the uptake and establishment of introduced DNA. There are two main methods of transforming plant cells and tissues: (a) The gene gun method which has been especially useful in transforming monocot species like corn and rice and (b) the Agrobacterium method which is considered preferable to the gene gun.

Agrobacterium tumefaciens is a soil-dwelling bacterium that has the ability to infect plant cells with a piece of its DNA. When the bacterial DNA is integrated into a plant chromosome, it effectively hijacks the plants' cellular machinery and uses it to ensure the proliferation of the bacterial population.

4. Selection of successfully transformed tissues following the gene insertion process to be transferred to a selective medium containing an antibiotic. Only plants expressing the selectable marker gene will survive and possess the transgene of interest.

5. Regeneration of whole plants under controlled environmental conditions in a series of media containing nutrients and hormones (a process that is known as tissue culture).
This process is performed mainly for the production of insect- or herbicide-resistant crops which are called Genetically Modified Crops (Fiester 2006).

\section{Bt crops}

$B t$ crops are plants genetically engineered (modified) to contain the endospore (or crystal) $B t$ toxin to be resistant to certain insect pests. "Plant Genetic Systems", in Belgium, was the first company to produce a $B t$ crop (tobacco) in laboratory in 1985 but the crop was not commercially successful (Vaek et al. 1987). However, in 1995, the Environmental Protection Agency (EPA) in the USA approved the commercial production and distribution of the $B t$ crops (corn, cotton, potato, and tobacco). Currently, the most common $B t$ crops are corn and cotton (Vaek et al. 1987). In 2013, four insect-resistant Bt brinjal (eggplant) varieties were approved for seed production and initial commercialization in Bangladesh (Koch et al. 2015). Recently, Bt soybean varieties expressing Cry1Ac+ Cry1Ab were approved for commercial use in Latin America to control lepidopteran insects (Koch et al. 2015). Bt crops, containing $B t$ toxins, were planted in almost 100 million ha (Brookes and Barfoot 2017).

The most widely used $B t$ vegetable crop is sweet corn. Shelton et al. (2013) compared sweet corn varieties grown in the USA where the primary insect pest was Heliothis zea and demonstrated that non-sprayed Bt varieties produced more clean marketable ears than corn varieties sprayed with chemical insecticides up to 8 times.

Adoption of $B t$ cotton has greatly reduced the abundance of targeted pests in cotton and other crops close to cotton that are infested by polyphagous target insects (Naranjo 2011). In addition, the reduction in insecticide use enabled IPM programs in Bt crops fields and the increase of natural enemies populations.

\section{Bacillus thuringiensis (Bt) History of $B t$}

$B t$ was first discovered in 1901 by the Japanese biologist Shigetane Ishiwatarias a cause of sotto disease that was killing silkworms and named it Bacillus sotto (Milner 1994). In 1911, Ernst Berliner isolated this bacterium from dead Mediterranean flour moth in Thuringia, Germany, and named it Bt. In 1915, Berliner reported the existence of a parasporal body, or crystalline inclusion (called crystal) close to the endospore within $B t$ spore (Fig. 1), but the activity of the crystal was not then discovered (Milner 1994). In 1956, it was found that the main insecticidal activity against lepidopteran insects was due to the parasporal crystal (Milner 1994). Zakharyan (1979) reported the presence of a plasmid in a strain of $B t$ and suggested that the plasmids involved in formation of endospore and crystal. 


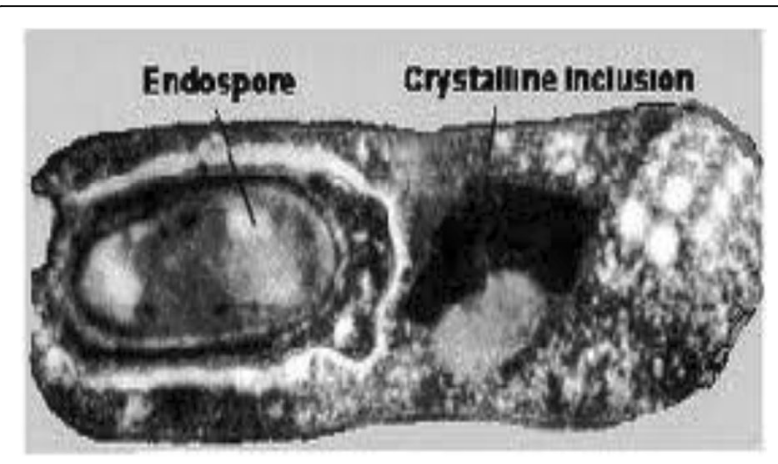

Fig. 1 The spore of Bacillus thuringiensis "from Hofte and Whitely (1989)"

In $1938, B t$ was commercially produced in France with the name Sporine to be used primarily to kill flour moth (Luthy et al. 1982). In 1956, Bt was used commercially in the USA, but the products were not successful because of poor formulations (Milner 1994). In the 1980s, the use of $B t$ increased worldwide when insects became increasingly resistant to the chemical insecticides (Milner 1994).

\section{The crystal}

The crystal, referred to as Cry toxin (cry from crystal), insecticidal crystal protein, parasporal body, crystalline inclusion, or delta endotoxin, is a protein formed during sporulation in $B t$ strains and aggregate to form crystals. Such Cry toxins are toxic to specific species of insects belonging to Lepidoptera, Coleoptera, Hymenoptera, Diptera, and Nematoda. They are harmless to human, vertebrates, and natural enemies of insects (Hofte and Whitely 1989).

In addition to the Cry toxins, some strains of $B t$, like $B t$ israelensis, produce another toxic crystal, named cytolytic protein or Cyt toxin. The Cyt toxin (or protein) derived its name from being cytolytic to a wide range of invertebrate and vertebrate cells in vitro. This Cyt toxin increases the efficiency of $B t$ in dipteran insects (suborder: Nematocera) and some coleopteran ones. The Cyt toxins are also formed during sporulation and occur within the parasporal body but in a separate inclusion. They share no significant amino acid sequence identity with Cry toxins and are thus unrelated (Hofte and Whitely 1989).

\section{Mode of action of $B t$}

$B t$ spores have to be ingested by the susceptible insect to cause mortality. The Cry toxin becomes active by proteoletic enzymes in the alkaline gut juice ( $\mathrm{pH} 8-10)$. Most cry toxins are actually pro-toxins of about 130 to $140 \mathrm{kDa}$, and after activation, they become $60-70 \mathrm{kDa}$ (Bravo et al. 2007). The activated toxin passes through the peritrophic membrane and binds to specific receptors on apical microvillar brush border membrane of the epithelial cells of the midgut making pores through which the toxin penetrates to such cells that become swollen. The swelling continues until the cells lyse and separate from the basement membrane of the midgut epithelium. The alkaline gut juices then leak into the hemocoel causing the hemolymph $\mathrm{pH}$ rises that leads to paralysis and death of the insect (Soberon et al. 2010). However, Broderick et al. (2006) mentioned that the naturally occurring bacteria in the gut (E.coli and Enterobacter) penetrate to the hemocoel through the disrupted epithelium caused by $B t$ toxins and multiply causing sepsis of the hemolymph and death of the insect. In the $B t$-moderately sensitive insects, such as Spodoptera spp., the endospore has a considerable role in killing the insect by producing toxins during its vegetative growth in the hemolymph (Crickmore et al. 2014). The insect or any living organism that does not have the receptors in gut epithelial cells is not killed by Bt (Gill et al. 1992).

The Cyt toxin is also a protoxin, about $28 \mathrm{kDa}$, and is activated by the proteolytic enzymes in the midgut juice to become $24 \mathrm{kDa}$. The toxin then penetrates from peritrophic membrane and the epithelial cells which lyse and separate causing the death of the insect (Hofte and Whitely 1989).

\section{Nomenclature of Cry and Cyt toxins (proteins)}

In the early 1980s, it was discovered that "there are genes responsible of the production of the crystal proteins in $B t$ spore and these genes are carried on plasmids" (Crickmore et al. 1998). Hofte and Whitely (1989) termed these "cry genes" and the protein they encode "cry proteins" (for crystal) and cyt proteins (for cytolytic). They classified these genes, or crystals, based on the spectrum of activity of the proteins (insect order), their size or mass, and their apparent relatedness as deduced from nucleotide and amino acid sequences.

This designation was followed by a Roman numeral that indicates patho-type (I and II for toxicity to lepidopterans, III for toxicity to coleopterans and IV for toxicity to dipterans). This numeral was followed by an uppercase letter indicating the chronological order in which genes with significant differences in nucleotide sequences were described.

As the number of Bt Cry and Cyt toxins increased, the nomenclature of Hofte and Whitely (1989) was modified as follows: the Cry and Cyt were maintained but the Roman numerals were replaced with Arabic numbers (Cry1 and Cry2 for toxicity to lepidopterans; Cry3 for toxicity to coleopterans; Cry4, Cry10, and Cry11 for toxicity to dipterans). The numbers $(1,2,3, \ldots .$.$) indicate$ major relationships (90\% identity). The uppercase letters (A, B, C....) indicate 95\% identity. Minor variations were designated by lowercase letters (a, b, c....), for example, Cry1Aa, Cry2Ab, ...... (Table 1). So, the structure of Cry1Aa differs slightly from that of Cry1Ab. 
Table 1 Nomenclature for representative insecticidal proteins and their encoding genes from Bacillus thuringiensis

\begin{tabular}{|c|c|c|c|c|c|c|}
\hline \multicolumn{2}{|c|}{ Old nomenclature ${ }^{a}$} & \multicolumn{2}{|c|}{ New nomenclature ${ }^{\mathrm{b}}$} & \multirow[t]{2}{*}{ Insect spectrum } & \multirow{2}{*}{$\begin{array}{l}\text { Number } \\
\text { of } \\
\text { amino } \\
\text { acids }\end{array}$} & \multirow[t]{2}{*}{ Mass $(k D a$} \\
\hline Gene & Protein & Gene & Protein & & & \\
\hline crylA(a) & CrylA(a) & crylAa & CylAa & Lepidoptera & 1176 & 133.2 \\
\hline $\operatorname{cry} \mid A(b)$ & CrylA(b) & crylAb & CrylAb & Lepidoptera & 1155 & 131.0 \\
\hline $\operatorname{cry} \mid A(c)$ & CrylA(c) & crylAc & CrylAc & Lepidoptera & 1178 & 133.3 \\
\hline crylB & CrylB & crylBa & CrylBa & Lepidoptera & 1207 & 138.0 \\
\hline crylC & CrylC & crylCa & CrylCa & Lepidoptera & 1189 & 134.8 \\
\hline crylD & CrylD & crylDa & CrylDa & Lepidoptera & 1165 & 132.5 \\
\hline cryllA & CryllA & cry $2 \mathrm{Aa}$ & Cry2Aa & Lepidoptera /Diptera & 633 & 70.9 \\
\hline cryllB & CryllB & cry $2 A b$ & CryzAb & Lepidoptera & 633 & 70.8 \\
\hline cryllIA & CryllIA & cry3Аa & Cry3Aa & Coleoptera & 644 & 73.1 \\
\hline cryllIB & CryllIB & cry3Ba & Cry3Ba & Coleoptera & 649 & 74.2 \\
\hline crylvA & CrylvA & cry4Aa & Cry $4 \mathrm{Aa}$ & Diptera & 1180 & 134.4 \\
\hline crylvB & CrylvB & cry4Ba & Cry4Ba & Diptera & 1136 & 127.8 \\
\hline crylve & Crylve & cry $10 \mathrm{Aa}$ & Cry $10 \mathrm{Aa}$ & Diptera & 675 & 77.8 \\
\hline crylVD & CrylvD & cryllAa & Cry11Aa & Diptera & 643 & 72.4 \\
\hline Jeg80 & Jeg80 & cryllBa & Cry $11 \mathrm{Ba}$ & Diptera & & 80 \\
\hline cytA & CytA & cyt1Aa & CytlAa & Diptera /others & 248 & 27.4 \\
\hline cytB & CytB & cyt2Aa & Cyt2Aa & Diptera & & \\
\hline
\end{tabular}

${ }^{\mathrm{a} F r o m ~ H o f t e}$ and Whitely (1989) microbiological review, 53, 242-255

${ }^{\mathrm{b}}$ For a complete list of crystaline proteins, see Crickmore (2017) 79

For more and recent information about nomenclature of Bt toxins, see Crickmore (2017).

The crystal often contains one or more Cry toxins (or genes). For instance, the crystal of Bt kurstaki contains four cry genes (or toxins); Cry1Aa, Cry1Ab, Cry1Ac, and Cry2Aa (Fig. 2). In contrast, Bt thompsoni contains only one cry toxin: Cry3Aa. The existence of more than Cry toxin in a $B t$ strain increases the efficiency and the host range of this strain.

The crystal of Bt israelensis, however, contains four Cry toxins (or genes): Cry4Aa, Cry4Ba, Cry10Aa, and Cry11Aa in addition to two Cyt toxins, Cyt1Aa, and Cyt2Ba (Ben-Dov 2014) (Fig. 2). Despite the low toxicity of the two Cyt toxins, they are highly synergistic with the Cry toxins that increase the toxicity of $B t$ israelensis by $3-5$-folds than the Cry proteins alone (Ben-Dov 2014).

Interestingly, Palma et al. (2014) reported that 700 Bt cry genes (Cry proteins) have been identified in the past decades. While many Cry proteins have pesticidal properties against insect pests in agriculture, others have no known invertebrate targets and have been termed "parasporins". Some of this parasporin group of $B t$ Cry proteins such as Cry31A, Cry $41 \mathrm{~A}$, Cry46A and Cry64A exhibit strong and specific cytocidal activity against human cancer cells of various origins. They have been given the alternative names: parasporin-1

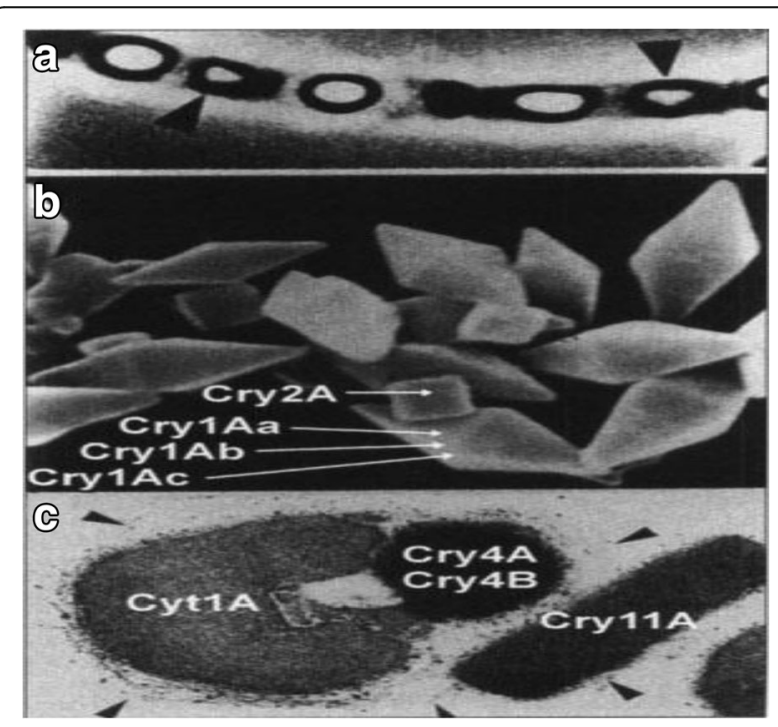

Fig. 2 Crystal of Bt kurestaki and Bt israelinsis "From Hofte and Whitely (1989)". a Bt spore. b Crystal of Bt kurestaki. c Crystal of Bt israelensis. The arrows in $\mathbf{a}$ illustrating the endospore (on the left) and the crystal (on the right) 
(PS1), parasporin-2 (PS2), parasporin-3 (PS3), parasporin-4 (PS4), parasporin-5 (PS5), and parasporin-6 (PS6).

\section{DNA, gene, and plasmid}

DNA (deoxyribonucleic acid) is a very large molecule that carries the genetic instructions used in growth, development, functioning, and reproduction of all living organisms and many viruses. It consists of two long nucleotide chains. The nucleotides are composed of a five-carbon sugars to which are attached one or more phosphate group and a nitrogenous base. The sugar is deoxyribose attached to a single phosphate group (representing the backbone of the DNA). The base may be either adenine (A), guanine (G), thiamine $(\mathrm{T})$, and cytosine $(\mathrm{C})$. The nucleotides are linked together in a chain through the sugar and phosphates (Rettner 2017) (Fig. 3).

A gene is a distinct segment of DNA that encodes the information necessary for the assembly of a specific protein. The protein then functions as enzyme to catalyze biochemical reactions, or as a structure or a storage unit of a cell to contribute to expression of a plant trait (Rani and Usha 2013).

A plasmid (Fig. 4) is a small DNA molecule. It naturally exists in bacterial cells and some eukaryotes. Often, the genes carried in plasmids provide the bacteria advantages such as antibiotic resistance (Roh et al. 2007)

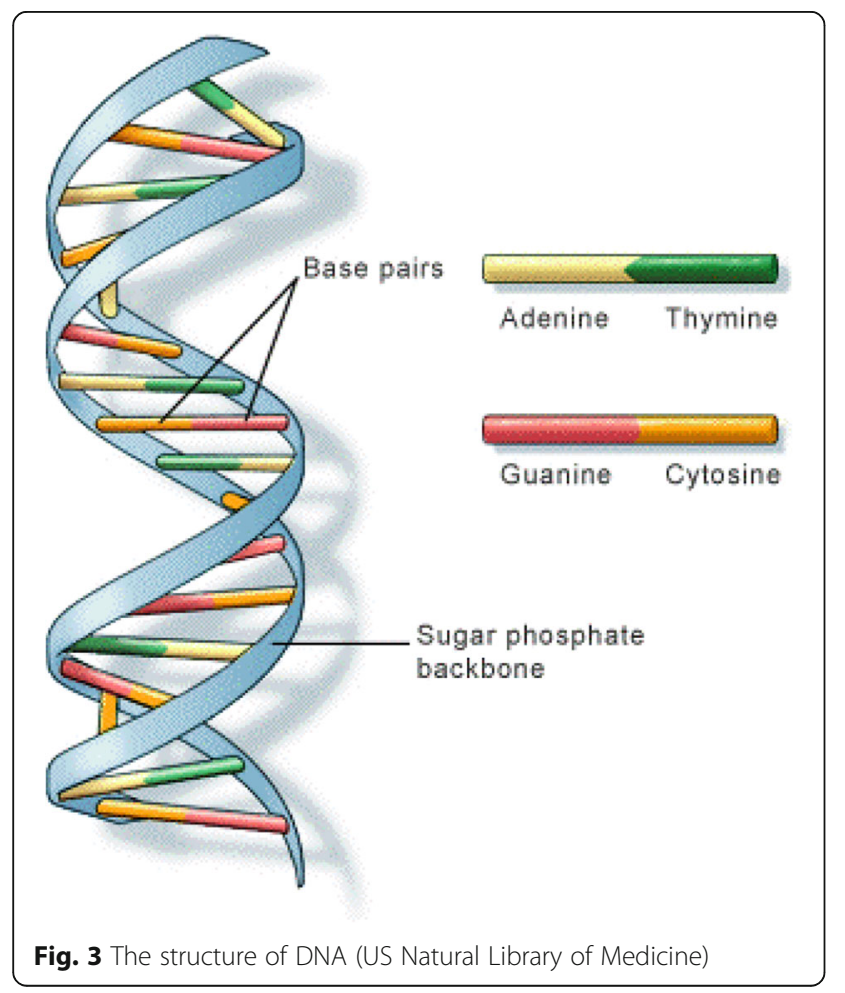

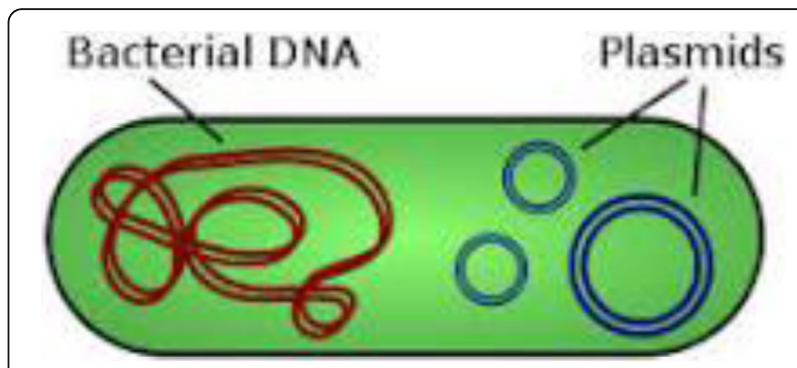

Fig. 4 Diagram of the endospore of Bt (from Google)

\section{Vegetative insecticidal proteins (Vip) toxins}

In addition to -indotoxins (Cry and Cyt toxins), $B t$ produces a novel family of insecticidal proteins named vegetative insecticidal proteins (Vip) during its vegetative stage. Two classes of Vip toxins were described. The first consists of a binary system composed of two proteins: Vip 1 and Vip 2, which are $100 \mathrm{kDa}$ and $52 \mathrm{kDa}$ in size, respectively. These proteins are highly toxic to certain coleopteran species (Chakroun et al. 2016). The second class is of a $88.5 \mathrm{kDa}$ protein (Vip 3) and active against a wide range of lepidopteran insects (Chakroun et al. 2016). These two classes of proteins do not display sequence homology with Cry or Cyt proteins (Chakroun et al. 2016). There are, to date, about 82 identified Vip genes. The Vip toxins do not form crystals.

Currently, available $B t$ cotton varieties produce either or both Cry toxins and Vip toxins that target specific caterpillar pests such as beet armyworm, Spodoptera exigua; cotton bollworm, Helicoverpa armeigera; and tobacco budworm, Heliothis virescens.

\section{Bt corn (maize)}

Corn is the sole $B t$ crop commercially produced and sold in 5 European countries (Spain, Portogal, Romania, the Czech Republic, and Slovania) (Koch et al. 2015) and is used for feeding livestock and as row material for the starch industry. Such countries produce approximately 173 million tones ensilage maize and 56 million tons of grain maize. A part of the $B t$ corn seeds is used for manufacturing food products, like starch, cornflakes, popcorn, canned sweet corn, corn on the cob, and corn oil, as the high heat used for producing such foods breaks down any toxins. There are rules in Europe countries that all food products made from $B t$ corn must be labeled. The USA and Canada, however, do not have such rules, and almost $75 \%$ of their manufactured corn products are made from $B t$ corn (Anonymous 2012).

Cultivation of $B t$ corn started in the USA, Canada, and Europe (Spain) in 1997, and by 2009, it was commercially planted in 11 countries. It was then representing $85 \%$ of the total area of corn in USA, $84 \%$ in Canada, 83\% in Argentina, 57\% in South Africa, 36\% in Brazil, $20 \%$ in Spain, and 19\% in Philippines (James 2016). In 2016, GM corn in the world (in 16 countries) reached 
60.6 million ha, out of which 6 million (10\%) were $B t$ corn, 7 million (11.7\%) were herbicide-tolerant corn, and 47.7 million (78.7\%) were combined $B t$ and herbicide-tolerant corn. The crop was produced to resist the infestation by the European corn borer, Ostrinia nubilalis, but later in the 2000s, it has been produced against the corn earworm, $H$. zea, and the corn rootworm, Diabrotica virgifera in addition to $O$. nubilalis (James 2016).

\section{Bt cotton}

For cotton growers, there was a lot of pressure from pests before the introduction of $B t$ cotton. Due to synthetic insecticide resistance, farmers were losing much of their cotton because of $H$. virescens and pink bollworm, Pectinophora gossypiella. According to USDA, $94 \%$ of the cotton cultured in USA is genetically modified (James 2016).

A study in University of California revealed that the average cost reduction in pesticides applied in $B t$ cotton fields from 1996 to 1998 was between 25 and 65 dollars per acre; the yield estimated, in the same period, was 5\% more, on average, than the traditional cotton. In addition, $B t$ cotton significantly decreased the number of foliar sprays, against other cotton pests and consequently the cost of insecticides (Anonymous 2000).

In 1996, Bollgard cotton (a trademark of Monsanto Company) was the first $B t$ cotton to be marketed in the USA. It was producing Cry1Ac toxin with high activity on tobacco budworm and pink bollworm. Bt cotton was widely adopted in the USA by farmers in the Western Cotton Belt for the pink bollworm and by farmers in the Mid-south and South-east for primarily tobacco budworm and to a lesser extent for fall armyworm, Spodoptera frugiperda and S. exigua (Stewart 2007).

Bollgard II was introduced in 2003 representing the next generation of $B t$ cotton. It was producing Cry $2 \mathrm{Ab}$ toxin. Wide Strike cotton (a trademark of Dow Agro-sciences) was produced in 2004 containing Cry1Ac and Cry1F. Both Bollgard II and Wide Strike have better activity on a wide range of caterpillar insects than the original Bollgard (Stewart 2007).

The most recent $3 \mathrm{rd}$ generation of Bt cotton contained three genes: Bollgard 3 (Cry1Ac + Cry2Ab + Vip3A), Twin Link Plus (Cry1Ab + Cry2Ac + Vip3Aa19), and Wide Strike 3 (Cry1Ac + Cry1F + Vip3A) (Vyavhare 2017).

$B t$ cotton is the only $B t$ crop cultivated in developing countries (James 2016). In India and China, the cultivated area of $B t$ cotton increased sharply during 2006 and 2007 to reach 25 million acres ( 2.5 million ha). Cultivation of $B t$ cotton in India started in 2002 (James 2016). In 2016, the world total area of cotton was 35 million ha (in 18 countries), out of which 22.3 million (64\%) were GM cotton. In the USA, however, the total area of cotton was 4 million ha and out of which 3.2 million ha $(80 \%)$ were combined $B t$ and herbicide-tolerant cotton (James 2016).

Varieties of $B t$ corn and $B t$ cotton registered in the USA were producing 18 different combinations of $11 \mathrm{Bt}$ toxins. Each variety produces $1-6 B t$ toxins that kill caterpillars, beetles, or both (Tabashnik et al. 2009).

\section{Insects resistance to $B t$ crops}

Insects' field-evolved resistance is defined as a genetically based decrease in susceptibility of a population to a toxin caused by exposure of the population to the toxin in the field. The main goal of monitoring resistance of insects to $B t$ crops is to detect resistance early enough to enable taking preventative measures before failures occur (Tabashnik 1994).

Strong evidence of field-evolved resistance to the $B t$ toxins in transgenic crops was reported for some populations of three noctuid insects; the stem borer, Busseola fusca, H. zea, and S. frugiperda (Matten et al. 2008). Field-evolved resistance of $S$. frugiperda to Bt corn producing Cry1F occurred in 4 years in Puerto Rico, USA (Matten et al. 2008). This was the first case of resistance leading to withdrawal of a $B t$ crop from the market (Matten et al. 2008). Field-evolved resistance of $B t$ corn producing Cry1 Ab was found in a population of the stem borer, B. fusca, in South Africa in 8 years or less (Van Rensburg 2007). A second resistant populations of B. fusca to Bt corn was detected in another area in South Africa (Kruger et al. 2009). The percentage of farmers reporting medium or severe damage to $B t$ corn from $B$. fusca rose from $2.5 \%$ in the 2005-2006 growing season to $58.8 \%$ in the 2007-2008 season. In the USA, field-evolved resistance of $H$. zea to $B t$ cotton producing Cry1Ac was noticed in some populations of the insect in 7-8 years in the southeastern USA (Luttrel and Ali 2007). In China, evidence of field-evolved resistance to Cry1Ac expressing $B t$ cotton was detected in populations of $H$. armigera (Liu et al. 2010).

In contrast, strong evidence of sustained susceptibility to the $B t$ toxins in transgenic crops was reported for populations of 8 target insects on $B t$ corn and $B t$ cotton after $4-8$ years. These insects were $H$. armigera, $H$. virescens, H. punctigera, P. gossypiella, D. grandiosella, D. saccharalis, $O$. nubilalis, and Sesamia nonagrioides (Tabashnik et al. 2009). However, In November 2009, Monsanto Company declared that P. gossypiella could develop resistance on $B t$ cotton producing Cry1Ac in four districts in India. As a solution for this problem the company produced another $B t$ cotton expressing Cry1 Ac + Cry1Ab (Bagla 2010).

\section{Safety of $B t$ crops}

According to companies, like Monsanto, which produce genetically engineered crops containing Cry toxins, such 
toxins are supposed to be active only against particular insects and should have no deleterious effect on the environment or on mammals and humans (Mendelshon et al. 2003).

\section{Safety to environment}

Most of the Cry proteins deposited into soil by $B t$ crops were degraded in soil within a few days, and they had no effect on soil bacteria, actinomyces, fungi, protozoa, algae, nematodes, or earthworm. Bt corn or Bt cotton were found to have no significant effect on populations of beneficial insects. In addition, the remains or pollen of $B t$ crops had no hazards to the non-target plants in the fields of $B t$ crops (Mendelshon et al. 2003).

In laboratory studies at Cornell University (USA) in 1999, it was found that the pollen in Bt corn had deleterious effects on larvae of the Royal (or Monarch) Butterfly, Cithoroni aregalis (Losey et al. 1999). However, Proceedings of National Academy of Science revealed that the results of six laboratory and field studies showed that the density of $B t$ toxin in $B t$ corn pollen is not enough to cause any harm to the insect larvae (Sears et al. 2001). It is to be noted that monarch butterfly has a beautiful coloration with about 15 -cm wing-span width and it is a matter of home-decoration in the USA.

\section{Effect on the secondary pests}

$\mathrm{Lu}$ (2010) reported that annual cultivation of $B t$ cotton resulted in high infestation levels by the sucking mirid insects in China which became the key pest on Bt cotton. Similarly, the continuous cultivation of $B t$ cotton caused obvious infestation by aphids and mealybugs in India (Losey et al. 1999). Laboratory tests conducted by Liu et al. (2005) showed that Aphid gossypii fed on Bt cotton had shorter reproductive duration, maximum lifespan, and an earlier peak of daily mortality in the 1st and 2nd generations compared to individuals fed on non- $B t$ cotton.

In addition, Lu et al. (2012) reported that after 20 years (1990-2010), a remarkable decline in aphid populations was noticed in $B t$ cotton fields in 36 locations in 6 districts north of China.

\section{Safety to predacious insects}

In laboratory studies, Mendelshon et al. (2003) found that pollen containing Cry toxins, which was at relatively very high doses, was not toxic to lady beetles (Coccinellids), green lacewings (Chrysoperla spp.), or honeybees. Also, field studies revealed that beneficial arthropods were substantially more abundant in $B t$ crops than in crops treated with chemical pesticides. Lu et al. (2012) reported a remarkable decline in aphid populations in $B t$ cotton fields in 36 locations in 6 districts north of China. They related this decline to the increase of the populations of the coccinellids, chrysopids, and spiders. In addition, these increased populations of the predators on $B t$ cotton had a considerable role for insect biological control on cotton, corn and peanut crops adjacent to $B \mathrm{t}$ crops.

In another field study it was found that the populations of prevailing predators in a $B t$ corn field did not differ significantly from those on a conventional corn field. These predators were Hyppodamia convergens, Orius insidiosus, and Scymnus spp. (Al-Deeb and Wilde 2003).

A 6-year field study assessed the long-term impact of Bt cotton producing Cry1Ac toxin on 22 species and strains of foliar-dwelling natural enemies in Arizona (Naranjo 2005). The study revealed no chronic, long-term effects of $B t$ cotton on such natural enemies.

A 3-year field study was carried out by Moar et al. (2004) in the USA to estimate the effects of Bt cotton (Bollgard) on biological control agents. They concluded that there were no adverse effects on non-target arthropods (parasitoids and predators) in Bollgard cotton fields compared to conventionally grown cotton ones.

In Egypt, Dahi (2013) reported that Bt cotton producing Cry1Ac and Cry2Ab did not affect the populations or abundance of common predators species prevailing in cotton fields.

In 2009, Angelika Hilbeck's team (ETH) in Zurich (Schmidt et al. 2009) published laboratory findings indicating that larvae of the two-spot ladybird, Adalia bipunctata, can be harmed by $B t$ toxins. The publication played a key role in justifying the cultivation ban for $B t$ maize MON810 in Germany imposed by Germany's Environment Minister in April 2009 (Alvarez-Alfageme et al. 2010). In 2010, a paper was published by Jorg Romeis and his team at Switzerland's Puplic Agroscope Researh Station in Zurich (Alvarez-Alfageme et al. 2010) which assessed the findings of Hilbeck's group. The paper presented that the quantities of $B t$ toxins that ladybird larvae could be exposed to in the field are not expected to have any negative impact on such larvae.

In February 2012, the Hilbeck's group published a further study (Hilbeck et al. 2012), in response to the 2010 publication of the Romeis group. They accused the Romeis group of using a different test method and this method was the reason for the difference in the results. They mentioned that combining the test methods from both groups showed that $B t$ toxin can indeed have a harmful effect on two-spot ladybird larvae. The result of Hilbeck's group (Schmidt et al. 2009) was obtained by feeding ladybird larvae on eggs of the Mediterranean flour moth, Ephestia kuehniella that had been sprayed with $B t$ toxin solutions at different concentrations. They then found a higher mortality rate among the treated larvae compared to the control group. Romeis group examined ladybird larvae under the microscope and found 
that the larvae only suck the contents of the eggs and do not eat even a part of the egg shell which was sprayed with the Bt toxin (Alvarez-Alfageme et al. 2010). Consequently, the larvae are not exposed to the $B t$ toxin. In 2012 paper, Hilbeck's group also observed ladybird larvae under the microscope and mentioned that the larvae bite into the eggs and when the contents spill out they come into contact with the egg shell sprayed with the toxin (Hilbeck et al. 2012). However, they added that in the field, ladybird larvae are only be exposed to potentially harmful quantities of $B t$ toxins if the feed on $B t$ corn pollen or on prey, except aphids, accumulate $B t$ toxins; aphids only suck plant sap which does not contain $B t$ toxin.

In another study, the red spider mite, Tetranichus urtica was used as food for the larvae of A. bipunctata. The red spider mite is a natural prey of the ladybird and was fed on $B t$ corn before exposed to the larvae. The mortality rate of the treated larvae was not significantly different from that of the control group which was fed on conventional corn. This study confirmed that $B t$ crops are not harmful to the two-spotted ladybird (Romeis et al. 2012).

Hilbeck et al. (1998), in laboratory studies, fed 2nd and 3rd larval instars of the predator, Chrysoperla carnea on artificial diet mixed with Cry1Ab toxin. They found that the total mortality in larvae was significantly higher (57\%) than in the untreated control (30\%). Also, significantly more larvae died $(29 \%)$ when received Cry1 Ab later during their development compared to the control ones (17\%). Although mortality was higher, almost no differences in developmental time were observed between treated and untreated larvae. In another study (Hilbeck et al. 1999), almost similar results were obtained when C. carnea larvae were fed on Spodoptera littoralis larvae fed on diet mixed with $\mathrm{Cry} 1 \mathrm{Ab}$ and Cry2A at different concentrations.

However, Moussa et al. (2018) reported that feeding larvae of Chrysoperla carnea on aphids reared on Bt corn until pupation did not affect percentages of pupation or adult emergence of the predator.

\section{Safety to honeybees}

Laboratory feeding studies carried out by Rose et al. (2007) showed no effects on the weight and survival of honeybees fed on Cry1Ab sweet corn pollen for 35 days. In field studies, colonies foraging in sweet corn plots and fed on $B t$ pollen cakes for 28 days showed no adverse effects on bee-weight, foraging activity and colony performance. Brood development was not affected by exposure to Bt pollen. Feeding the 2nd instar larvae on pure $B t$ toxins mixed with their food on concentrations far above those to which they would be exposed showed insignificant mortality rate between the treated larvae and the control group.

Duan et al. (2008) examined 25 studies that independently assessed potential effects of $B t$ toxins on honey bee survival and found that the Cry proteins did not negatively affect the survival of either honey bee adults or larvae in laboratory.

\section{Are Bt crops safe to mammals and humans? World controversy}

The results of experiments conducted by researchers at the University of Caen, France, and supported by GEKKO Foundation, in Germany, showed that toxins produced in $B t$ corn, Mon810, can impact significantly the viability of human cells. The effects were observed with relatively high concentrations of the toxins; however, further investigations should be conducted to find out how such toxins impact the cells. In addition, it should be taken into account if there are combination effects with other compounds in the food (Mesnage et al. 2011). By introducing the toxin-gene into the plant, the structure of the toxin is modified and may cause its selectivity to be changed. Many Bt corn, like Smart Stax, produce $2-6$ different $B t$ toxins and therefore have a higher content of toxins (Mesnage et al., 2012).

In 2001, the Environmental Protection Agency (EPA) in the USA supervised comprehensive studies to reassess the 4 registered $B t$ crops that had been accepted for agricultural use since 1995. These crops were $B t$ corn (Cry1Ab), Bt corn (Cry1F), Bt cotton (Cry1Ac), and Bt potato $(\mathrm{Cry} 3 \mathrm{~A})$. The reassessment included the potential effects on the environment, the natural enemies, the non-target insects and the safety to human and mammals (Mendelshon et al. 2003). The results of the reassessment indicated that in vitro studies $B t$ toxins were unstable in the presence of digestive fluids of human's gut and were degraded in such fluids within 0-7 min. However, these studies did not ensure the non-toxicity of these toxins to human or that the rapid degradation occurs in all Cry toxins. The Cry1Ab and Cry1Acin processed corn foods (popcorn, tachoshell, cornflex, starch, oil, etc.) are not heat-stable and accordingly become inactive in such foods. No acute toxicity was shown in mice treated with high doses of $B t$ toxins, $3280-5000 \mathrm{mg} / \mathrm{kg}$ body weight.

Wang et al. (2002) found that feeding mice on Bt rice flour (Cry1Ac) at a dose of $64 \mathrm{mg}$ of the toxin/ $/ \mathrm{kg}$ body weight for 90 days did not cause any effect in the tissues of the liver, kidney, intestines, or blood cells. In addition, no significant differences in the weights of such organs between treated and untreated mice.

Hall (2011) mentioned that the risks of $B t$ foods to human health appear small based on what is known about the bacterial endotoxin, its specificity and confidence of 
the process of plant transformation and screening. The tasks of determining the levels of such risks, however, are immense. Human diets are complex and variable, so, how can we trace the acute or chronic effects of eating $B t$ foods when they are mixed with many other foods that may also present their own health hazards? It is even more complicated to determine the indirect risk of eating meat from animals raised on transgenic crops. These tests take time and the results of clinical trials are not always clear-cut. It will likely take decades before knowing with any certainty if $B t$ crop is safe for human or not.

An analysis of blood and organ system was carried out with rats fed three main commercialized Bt maize (deVendomois et al. 2009). Approximately 60 different biochemical parameters were classified per organ and measured in serum and urine after 5 and 14 weeks of feeding. $B t$ maize-fed rats were compared first to their respective parent non- $B t$ equivalent control groups, followed by comparison to 6 groups which had consumed other non- $B t$ maize varieties. The analysis clearly revealed sex- and dose-dependent effects on the kidney and liver of the treated rats. Other effects were also noticed in the heart, adrenal glands, spleen, and hematopoietic system.

The French High Council of Biotechnologies Scientific Committee reviewed the 2009 Vendomois et al. study and concluded that "It presents no admissible scientific element likely to ascribe any hematological, hepatic, or renal toxicity to the three re-analyzed $B t$ maize (Anonymous 2010)." Also, a review by Food Standards Australia New Zealand of the 2009 Vendomois et al. study concluded that the results were due to chance alone. However, French government applied a principle of precaution against genetically modified crops. In addition, a review by Food Standards Australia New Zealand of the 2009 Vendomois et al. study concluded that the results were due to chance alone (Anonymous 2010).

A Canadian study in 2011 estimated the presence of Cry1Ab1 (Bt toxin) in non-pregnant women, pregnant women, and fetal blood. All groups had detectable levels of the toxin in blood, including $93 \%$ of pregnant women and $80 \%$ of fetuses at concentrations of $0.19 \pm 0.30$ and $0.04 \pm 0.04 \mathrm{ng} / \mathrm{ml}$, respectively (Anonymous 2010).

In 2004, a human feeding study was conducted to determine the effects of genetically modified (GM) food. Seven human volunteers were allowed to eat genetically modified soybean (resistant to the herbicide Roundup) to see if the DNA of GM soybean was transferred to the human gut bacteria. The examination of their guts showed that no recombinant DNA was found (Netherwood et al. 2004). However, the anti-GM crops advocates believe that the study needs additional testing to determine its significance (Smith 2007).

In a study funded by the European Arm of Greenpeace, it was found that there was a possibility of a slight but statistically meaningful risk of liver damage in rats (Seralini et al. 2007). However, this possibility of risk was reported to be of no biological significance by the European Food Safety Authority (Seralini et al. 2007).

Anilkumar et al. (2010) fed sheep (1 year old) on $B t$ and non-Bt cottonplants for 3 months and found that the histological examination of liver and kidney revealed no significant changes between $B t$ and non- $B t$ plant-fed sheep.

In a study in pigs and calves fed on $B t$ maize, it was found that Cry protein fragments were detectable, but reduced in size, as they travel down the gastrointestinal (GI) tract. None were detected in the liver, spleen, or lymph nodes indicating that they were too large to be systematically absorbed from the GI tract (Chowdhury et al. 2003). It was suggested that transgenic nucleic acid and proteins from GM crops are handled in the gut like their conventional counterparts, with no evidence for systemic absorption of intact proteins or genes (Sieradzki et al. 2013). Herman et al. (2006) reported that maize fed to animals is generally not processed and accounts for approximately $65 \%$ of their diet. As for human, the exposure to Cry protein is much lower than that of farm animals and the maize is processed by heating causing the Cry proteins to lose their insecticidal activity and make them more susceptible to degradation.

A number of Cry proteins (toxins) were subjected to in vitro heat stability studies under conditions similar to those used for human food processing (Hammond and Jes 2011). All Cry proteins tested lost insecticidal activity after processing. In general, there are fundamental biological properties of proteins that greatly limit their potential to produce chronic toxic effects when ingested (Hammond et al. 2013). The ingestion of proteins introduced to date into GM crops are not considered to be toxic based on their known biochemical function and on the results obtained from bioinformatics searches (Hammond et al. 2013).

In a safety study (Onose et al. 2008), rats were treated with famotidine (to reduce gastric acid secretion) and indomethacin (to damage the intestinal epithelium), then they were fed diets with and without Cry1 Ab protein (10 ppm). Despite the expectation of less Cry1Ab protein digestion and more absorption of Cry1 Ab protein into the circulatory system of the GI-impaired rats, there was no evidence of toxicological effects (changes in clinical blood parameters and histologic appearance of organs) in the treated rats.

Mezzomo et al. (2013) reported that $B t$ spore preparations containing various Cry proteins were found to cause hemato-toxocity in mice when administered by oral gavage. However, Koch et al. (2015) mentioned that such a result could be due to spore components other than Cry proteins. 
Domingo (2016) stated that with only a few exceptions, the reported studies in the last 6 years showed rather similar conclusions; the assessed GM soybeans, corn, rice, and wheat would be as safe as the parental species of these plants. However, in spite of the notable increase in the available information, studies on the long-term health effects of GM plants, including tests of mutagenicity, teratogenicity, and carcinogenicity seem to be still clearly necessary.

\section{StarLink corn and human allergy}

StarLink is a variety of $B t$ corn produced commercially for use in animal feed by Aventis Company in the USA. There was a stipulation that the crop must not be used for human consumption because the $B t$ toxin used in StarLink is less rapidly digested than the other $B t$ toxins. Twenty-eight people showed allergic reactions related to eating corn products that may have contained the StarLink toxin. However, the US Centers for Disease Control studied the blood of these people and concluded that there was no evidence that the allergic reaction was related to the StarLink toxin (Seralini et al. 2007).

\section{Ban of $B t$ crops}

In August 2003, Zambia cut-off the flow of genetic modified maize from UN's World Food Program. This left a famine-stricken population without food aid. In December 2005, the Zambian government changed its mind in the face of further famine and allowed the importation of GM maize (Anonymous b, 2009).

In April 2004, Hugo Chavez announced a total ban on GM seeds in Venezuela (Anonymous, 2009).

In January 2005, the Hungarian government announced a ban on importing and planting of GM maize seeds, which was subsequently authorized by the European Union (James 2016).

The Germany's Environment Minister issued a ban for cultivation of $B t$ maize in April, 2009, after published laboratory findings in Germany indicating that $A$. bipunctata larvae can be harmed by $B t$ toxins (Schmidt et al. 2009).

In 2014, the Minister of Agriculture in Egypt announced a ban on the cultivation of $B t$ cotton and maize after a debate on a TV program concerning the possibilities of hazards of $B t$ crops (unpublished).

In Hawaii, growing $B t$ cotton has been prohibited since 2013 (James 2016).

Burkina Faso, Africa top cotton producer, banned Bt cotton in 2016 because of economic and quality concerns (James 2016).

Romania decided not to plant GM crops in 2016 due to onerous requirement by the government (James 2016).

In 2015, European Commission announced that $19 \mathrm{EU}$ countries are able to ban the cultivation of GM crops. Although repeated scientific assessments have concluded that GM crops are as safe for humans and environment as the conventional crops, a majority of Governments, parliamentarians, and European people oppose cultivation of such GM crops (James 2016). The European countries that banned cultivation of GM crops made their decision because they prefer producing the organic food. These countries import over 30 million tons per year of Bt corn and GM soybeans as animal feed and livestock industry. However, Russia issued a ban on both cultivation and importing Bt crops (James 2016).

\section{Monsanto declared worst company of 2011}

Monsanto, a major biotech corporation responsible for genetically modified foods, has been given "the Worst Company of 2011 Award" for threatening both human health and the environment. The award was given by natural health information website Natural Society after thousands of readers voted "Monsanto the worst company of 2011" (Gucciardi 2011). Numerous scientific studies have found Monsanto's GM crops, herbicides and bio-pesticides, to be a danger to the planet. A review of 19 studies announced that consumption of GM corn or soybeans lead to significant organ disruptions in rats and mice, particularly in the liver and kidney (Gucciardi 2011).

\section{The end of Bt crops}

A report from Texas A \& MA griLife Extension stated that $B t$ cotton and corn have been attacked by bollworms and earworms among other pests. Cry toxins had a good run and will hang on for a while longer, but the era of the Cry toxins seems to be ending. They suggested that $B t$ crops should contain two or three different toxins to delay resistance. If an insect had an allele to survive on toxin 1 , it probably does not have different alleles to survive on toxins 2 and 3 (Anonymous 2016).

The report also claimed that the newest Vip (Vegetative insecticidal protein toxins) for caterpillars does a good job of controlling many species. Once again, the insects will have adapted, or partially adapted, to the old toxins, so selection for resistance will be on Vip and again the era of the Cry toxins seems to be ending (Anonymous 2016).

\section{No to a moratorium on the cultivation of GM maize}

A declaration of 500 European scientists indicated that amoratorium on the cultivation of GM $B t$ maize approved by the European Union (EU) is not scientifically justified. Such a decision could be based only on imaginary or false uncertainties concerning environmental or food safety. It would bring no new knowledge that could reduce the hypothetical risks that could be generated by the cultivation and the consumption of GM Bt maize. Such a moratorium would be in contradiction with the precautionary principle (Naud et al. 2007). 
Plant varieties obtained either by classical breeding or by gene transfer share a similar level of risk, which is low in both cases. Maize has been cultivated and eaten by humans for thousands of years without any negative effect for animal or human health despite the numerous genetic modifications undertaken during classical genetic selection. The insecticidal active toxin presents in $B t$ maize has been exploited for decades within the applied commercial compounds of Bacillus thuringiensis without any observed toxicity or allergic response (Naud et al. 2007).

\section{Conclusions}

This review shows that some researchers support the cultivation of $B t$ crops depending upon the results of their laboratory and field studies on the safety of such crops to environment and mammals. Others are against $B t$ crops as they may cause risk to human.

The article "Monsanto is Declared the Worst Company of 2011" claimed that the Award was given by natural health information website, Natural Society, after voting of thousands of readers. A review of 19 studies announced that consumption of GM corn or soybeans may lead to significant organ-disruption in rats and mice particularly in the liver and kidneys.

On the other hand, the article "No to a Moratorium on the Cultivation of GM Maize" claimed that the declaration was signed by 500 researchers in Europe. This declaration relies, as mentioned, on the following: (1) Any plant variety obtained either by classical breeding or by gene transfer has a similar level of risk which is little in both cases. (2) Bt-commercial bio-insecticide has been applied for decades without any toxic or allergic response being observed.

Finally, and from my point of view, it seems that this controversy could be attributed, in part, to a competition between the companies producing chemical insecticides and those producing bio-control agents. In addition, there are still scientists as well as crops producers worldwide that do not trust in the biological control of insects.

\section{Abbreviations}

Bt: Bacillus thuringiensis; Cry: Crystal; Cyt: Cytolytic; EPA: The Environmental Protection Agency; FDA: Food and Drug Administration; GMO: Genetically Modified Organisms; Vip: Vegetative insecticidal protein

\section{Author's contribution}

The author read and approved the final manuscript.

Ethics approval and consent to participate

Not applicable.

\section{Consent for publication}

I agree to publish the manuscript.

\section{Competing interests}

The author declares that he has no competing interests.

\section{Publisher's Note}

Springer Nature remains neutral with regard to jurisdictional claims in published maps and institutional affiliations.

Received: 2 January 2018 Accepted: 16 May 2018

Published online: 19 June 2018

\section{References}

Al-Deeb MA, Wilde GE (2003) Effect of Bt corn expressing Cry3Bb1 toxin for corn rootworm on above ground non-target arthropods. Environ Entomol 32(5): $1164-1170$

Alvarez-Alfageme F, Bigler F, Romeis J (2010) Laboratory toxicity studies demonstrating no adverse effects of Cry1 Ab, Cry3Bb to larvae of Adalia bipunctata. Transgenic Res 20:467-479

Anilkumar B, Gopala A, Kalukumar B, Usha M, Anjaneyulu Y, Gopi KS (2010) Serobiochemical studies in sheep fed on Bt cotton plants. Toxicol Int 17(2):99-101

Anonymous (2000) Bt cotton. www.bt.ucsd.edu/bt_cotton.html, pp 1-3

Anonymous (2009) Genetically modified food. https:/en.wikipedia.org/wiki/ genetically_modified_food_controversies, pp 1-11

Anonymous (2010) Genetically modified maize. http://en.wikipedia.org/wiki/ Genetically_modified_maize, pp 1-6

Anonymous (2012) Genetically modified maize in Europe. http://www. gmocompass.org/eng/grocery_shopping/crops/18.genetically_modified_, pp 1-2

Anonymous (2016) Current cotton scenario: cotton production and balance sheet. The Cotton Corporation of India Ltd, Navi Mumbai

Baeshen NA, Sheikh A, Bora RS, Ahmed MM, Ramadan HA, Radwan EM (2014) Cell factories for insulin production. Microb Cell Factories 13:1-9

Bagla P (2010) Hardy cotton-munching pests are latest blow to GM crops. Science 327(5972):1439

Ben-Dov E (2014) Bacillus thuringiensisvar.israelensis and its dipteran specific toxins. Toxins (Basel.) 6(4):1222-1243

Bravo A, Gill SS, Soberon M (2007) Mode of action of Bacillusthuringiensis cry and Cyt toxins and their potential for insect control. Toxicon 49:422-435

Broderick NA, Raffa KF, Handelsman J (2006) Midgut bacteria required for Bt insecticidal activity. Proc. Natl. Acad.Sci., USA 103(41):196-199

Brookes, G. and Barfoot, P. 2017. GM crops: global socio-economic and environmental impacts (1996-2015). Dorcester: PG Economics LTD. Online: www.pgeconomics.co.uk/pdf/2017globalimpactstudy

Chakroun M, Banyulls N, Bel Y, Ferre J (2016) Bacterial vegetative insecticidal proteins from entomopathogenic bacteria. Microbiol Mol Biol Rev 80: $329-350$

Chowdhury EH, Kuribara H, Hino A, Sultana B, Mikami O, Shimada N (2003) Detection of corn intrinsic and recombinant DNA fragments and Cry1 Ab protein in the gastrointestinal contents of pigs fed genetically modified corn. J Animal Sci 81:2546-2551

Crickmore N (2017) Bacillus thuringiensis toxins classification, pp 41-53. http://link. springer.com/chapter/10.1007/978-3-319-56678_3.pdf

Crickmore N, Zeigler DR, Feitelson J, Schnepf E (1998) Revision of the nomecluture for Bacillus thuringiensis pesticidal crystal proteins. Microbiol Mol Biol Rev 62(3):807-813

Crickmore, N.; Zeigler, D.R.; Schnepf, E.; Baum, J.; Bravo, A. and Dean, D.H. 2014. Bacillus thuringiensis toxins nomenclature. www.btnomencluture.infolifesci. sussex.ac.uk/Home/Neil_Crickmore/Bt (7 Nov. 2014)

Dahi HF (2013) Assessment of the effects of transgenic Bt cotton that contains Cry1 Ac and Cry2Ab toxins on the abundance of non-target organisms community. Journal Nature and Science (JNSCI) 11(2):117-122

deVendomois JS, Roullier F, Dominique C, Seralini G (2009) A comparison of the effects of three GM corn varieties on mammalian health. Int J Biol Sci: 5(7):706-26

Domingo JL (2016) Safety assessment of GM plants: an updated review of the scientific literature. Food Chem Toxicol 95:12-18

Duan JJ, Marvier M, Huesing J, Dively G, Huang ZY (2008) A meta-analysis of effects of Bt toxins on honeybees. PLoS One 3(1):e1415

Fiester A (2006) Why the omega 3 piggy should not go to market. Nat Biotechnol 24:1472-1473

Gill SS, Cowels EA, Pietrantonio PV (1992) The mode of action of Bt endotoxins. Annu Rev Entomol 37:615-636

Gucciardi A (2011) Monsanto declared worst company of 2011. http:// naturalociety.com/merck-monsanto-worst-company-award, pp 1-5 
Hall H (2011) Bt corn: is it worth the risk. http://www.scq.ubc.ca/bt-corn-is-itworth-the-risk, pp 1-3

Hammond BG, Jes JM (2011) Impact of food processing on the safety assessment for proteins introduced into biotechnology- derived soybean and corn crops. Food Chem Toxicol 49:711-721

Hammond BG, Kough J, Herouet GC, Jez JM (2013) Toxicological evaluation of proteins introduced into food crops. Grit Rev Toxixol 43(2):25-42

Herman R, Gao Y, Storer N (2006) Acid-induced unfolding kinetics in simulated gastric digestion of proteins. Regul Toxicol Pharmacol 46:93-96

Hilbeck A, Baumgartner M, Fried PM, Bigler F (1999) Effects of transgenic Bt cornfed prey on immature development of Chrysoperla carnea. Environ Entomol 27:480-487

Hilbeck A, McMillan JM, Meier M, Himbel A, Tertikova M (2012) A controversy, revisited: is Adalia bipunctata adversely affected by Bt toxins? Environ Sci Eur 24:10

Hilbeck A, Moar W, Pusztai-Garet M, Bigler F (1998) Toxicity of Bacillus thuringiensis Cry1Ab toxin to Chrysoperla carnea. Environ Entomol 27:1255-1263

Hofte H, Whitely HP (1989) Insecticidal crystal proteins of Bacillus thuringiensis. Microbiol Mol Biol Rev 53(2):242-255

James, C. 2016. Global status of commercialized Biotech/GM crops: ISAAA Brief No 52. (http://www.isaaa.org)

Koch MS, Ward JM, Levine SL, Baum GA, Vicini JL, Hammond BG (2015) The food and environmental safety of Bt crops. Front Plant Sci 6:283-336

Kruger M, Van Renzburg JJ, Van den Berg J (2009) Prospective on the development of the stem borer resistance to $B t$ maize and refuge compliance at the Vaalharts irrigation scheme in South Africa. Crop Port 28: 684-689

Liu F, Xu Z, Zhu YC, Huang F, Wang Y, Zhou W, Shen J (2010) Evidence of field evolved resistance to Cry1Ac expressing Bt cotton in Helicoverpa armigera in northern China. Pest Manag Sci 66:155-161

Liu XD, Zhai BP, Zhang XX, Zong JM (2005) Impact of transgenic cotton on Aphis gossypii. Ecol Entomol 30:307-315

Losey JE, Rayor LS, Carter ME (1999) Transgenic pollen harms monarch larvae. Nature 399:214

Lu YH (2010) Mirid bug outbreaks in multiple crops correlated with wide scale adoption of Bt cotton in China. Science 328:1151-1154

Lu YH, Kongming W, Yuying J, Yuyuan G, Nicolas D (2012) Widespread adoption of Bt cotton and insecticide decrease promotes biocontrol services. Nature 487:362-365

Luthy P, Cordier J, Fischer H (1982) Bacillus thuringiensis as a bacterial insecticide: basic considerations and application. In: Kurstack E (ed) Microbial and viral pesticides. Marcel Dekker, New York, pp 35-74

Luttrel, R.G. and Ali, M.I. 2007. Exploring selection for Bt resistance in heliothines: results of laboratory and field studies. Pp. 1073-1086. In: D.A Richter (ed.) Proceedings, 2007, Beltwide cotton conference, 9-12 January, 2007. New Orleans

Martineau B (2001) First fruit: the creation of the FlavSavr tomato and the birth of biotech foods. McGraw-Hill, p 269

Matten SR, Head GP, Quemada HD (2008) How governmental regulation can help the integration of Bt crops within IPM programs. In: Romois J, Shelton AM, Kennedy GG (eds) Integration of insect resistant genetically modified crops within IPM programs. Springer, New York, pp 27-39

Mendelshon M, Kough J, Vaituzis Z, Mathews K (2003) Are Bt crops safe? Nat Biotechnol 21(9):1003-1009

Mesnage R, Clair E, Gress S, Then C, Seralini GE (2011) Cytotoxicity of human cells of Cry1ab and Cry1Ac Bt insecticidal toxins alone or with glyphosphatebased herbicide. J Appl Toxicol:1-5

Mezzomo BP, Miranda AL, Freire IDS, Barbosa LCP, Lacava ZGM (2013) Hematoxicity of Bacillus thuringiensis as spore-crystal strains, Cry1Aa, Cry1Ab, Cry1Ac or Cry2Aa in Swiss albino mice. J. Hematol. Thromb. Dis 1:104

Milner RJ (1994) History of Bacillus thuringiensis. Agric Ecosyst Environ 49:9-13

Moar WJ, Eubanks M, Freeman B, Head G (2004) Effects of Bt cotton on biological control agents in the southeastern United States. 1st international symposium on biol. Control of arthropods, Honolulu

Moussa S, Baiomy F, Abouzaid K, Nasr M, Moussa EA, Kamel EA (2018) Potential impact of host pest fed on Bt corn on the development of Chrysoperla carnea (Neur.: Chrysopidae). Egypt. J. Biol. Pest Control 28(23):1-6

Naranjo SE (2005) Long term assessment of the effects of transgenic Bt cotton on the abundance of non-target arthropod natural enemies. Environ Entomol 34:1193-1210

Naranjo SE (2011) Empact of Bt transgenic cotton on integrated pest management. J Agric Food Chem 59:5842-5851
Naud, M.; Krivine, J.; Houdebine, L.M.; Kuntz, M.; Dattee, Y. and Fellous, M. 2007. No. to a moratorium on the cultivation of Gm maize. http://nonaumorattoire. fr/english.htmnonaumoratoire.free.fr/english.htm: pp. 1-3

Netherwood T, Martin-Orue SM, O-Donnel AG, Gilbert HG (2004) Assessing the survival of transgenic plant DNA in the human gastro-intestinal tract. Nat Biotechnol 22(2):204-209

Onose J, Imai T, Hasumura M, Ueda M, Ozeki Y, Hirose M (2008) Evaluation of subchronic toxicity of diatery administered Cry1Ab protein from Bacillus thuringiensis in male rats with chemically induced gastrointestinal impairment. Food Chem Toxicol 46:2184-2189

Palma L, Muhuz D, Berry C, Murillo J, Caballero P (2014) Bacillus thuringiensis toxins: an overview of their biocidal activity. Toxins 6:3296-3325

Rani SJ, Usha R (2013) Transgenic plants: types. Benefits and Future J Pharmacy Res 6:879-883

Rettner R (2017) DNA: definition, structure and discovery. www.livescience.com/ 37247-dna, p 3

Roh JY, Choi JY, Li MS, Jin BR, Je YH (2007) Bacillus thuringiensis as a specific, safe and effective tool for insect control. J Microbiol Biotechnol 17(4):547-559

Romeis J, Alvarez-Alfageme F, Bigler F (2012) Putative effects of Cry1Ab to larvae of Adalia bipunctata -reply to Hilbeck et al., 2012. Environ. Sci Eur 24:18

Rose R, Dively GP, Pettis J (2007) Effects of Bt corn pollen on honeybees: emphasis on protocol development. Apidologie 38:1-11

Schmidt J, Braun CW, Whitehouse IP, Hilbeck A (2009) Effects of activated Bt transgene products (Cry1 Ab and $\mathrm{Cry} 3 \mathrm{Bb}$ ) on immature stages of the ladybird, Adalia bipunctata in laboratory. Arch Environ Contam Toxicol 56: $221-228$

Sears MK, Hillmich RL, Stanley DE, Oberhouser KS, Pleasants JM (2001) Impact of Bt corn pollen on monarch butterfly populations: a risk assessment. Proceedings of the National Academy of science (PNAS) 98:11937-11943

Seralini GE, Cellier D, de Vendomois JS (2007) New analysis of a rat feeding study with a genetically modified maize reveals signs of haepatorenal toxicity. Arch Environ Cotam Toxicol 52(4):596-602

Shelton AM, Olmstead DL, Burkness EC, Hutchison WD, Dively G, Welty C (2013) Multi-state trials of Bt sweet corn varieties for control of the corn earworm. J Econ Entomol 106:2151-2159

Sieradzki Z, Mazur M, Kwiatek K, Swiatkiewicz S, Koreleski J (2013) Assessing the possibility of genetically modified DNA transfer from GM feed to broiler laying hen, pig and calf tissues. Pol J Vet Sci 16:435-441

Smith JM (2007) Genetic roulette: the documented health risks of genetically engineered foods, Fairfield

Soberon M, Pardo L, Monoz C, Sanchez J, Gomez I, Porta H (2010) Pore formation by toxins. In: Andeluh G, Lakey J (eds) proteins: membrane binding and pore formation. Landes bioscience and springer science, New York, pp 127-142

Stewart, S.D. 2007. Bt cotton. www.utcrops.com/cotton_insects/pubs/Wi29Btcotton

Tabashnik BE (1994) Evolution of resistance to Bacillus thuringiensis. Annu Rev Entomol 39:47-49

Tabashnik BE, Van Renzberg JJ, Carriere Y (2009) Field-evolved insect resistance to Bt crops: definition, theory, and data. J Econ Entomol 102(6):2011-2025

Vaek M, Reynaerts A, Hofte A (1987) Transgenic plants protected from insects. Nature 325(6125):33-37

Van Rensburg JJ (2007) First report of field resistance by stem borer, Busseo lafusca to Bt transgenic maize. S. African J. Plant Soil 24:147-151

Vyavhare, S.S. 2017. Bt cotton. Lubbock.tamu.edu./2017/Bt_cotton

Wang Z, Wang Y, Cui H, Xia Y, Altosar J (2002) Toxicological evaluation of transgenic rice flour from Bacillus thuringiensis. J Sci food and Agriculture 82(7):738-744

Zakharyan RA (1979) Plasmid DNA from Bacillus thuringiensis. Microbiologia 48(2): 226-229 